15. Intehrovane intelektualne upravlinnia tekhnolohichnymy protsesamy v ekonomichnykh systemakh korporatyvnykh pidpryiemstv hirnycho-metalurhiinoho kompleksu: monograph / Khorolskyi V. P. et al.; ed. by Khorolskyi V. P. Dnipropetrovsk: Sich, 2008. 443 p.

\section{РАЗРАБОТКА РОБОТОТЕХНОЛОГИЧЕСКОГО КОМПЛЕКСА ИНТЕЛЛЕКТУАЛЬНОГО УПРАВЛЕНИЯ ПРОИЗВОДСТВОМ ХЛЕБА ДЛЯ ТЕРРИТОРИЙ С ТЕХНОГЕННОЙ НАГРУЗКОЙ}

Разработан комплекс производства инновационных сортов хлеба для населения, проживающего на территориях с высоким уровнем загрязнения. Предложено в системе производства опары-теста использовать ультразвуковую кавитационную дезинтеграцию. Получены эмпирические зависимости, позволяющие идентифицировать и контролировать технологические процессы производства хлеба в среде роботов-интенсификаторов. Разработана архитектура многоуровневой системы интеллектуального управления поддержки принятия решений производством хлеба. ключевые слова: ультразвуковая кавитация, процесс опаратесто, производство хлеба, среда роботов-интенсификаторов.

Khorolskyi Valentin, Doctor of Technical Sciences, Professor, De partment of General Engineering Disciplines and Equipment, Donetsk National University of Economics and Trade named after Mikhail Tugan-Baranovsky, Kryvyi Rih, Ukraine, e-mail: Khorolv@ukr.net, ORCID: http://orcid.org/0000-0003-4040-3229

Korenets Yurii, Applicant, Department of Technology in Catering, Hotel and Restaurant Business, Donetsk National University of Economics and Trade named after Mikhail Tugan-Baranovsky. Kryvyi Rih, Ukraine, e-mail: yurii.korenets@gmail.com, ORCID: https://orcid.org/0000-0002-5873-7908

Ostapenko Ivan, Department of General Engineering Disciplines and Equipment, Donetsk National University of Economics and Trade named after Mikhail Tugan-Baranovsky, Kryvyi Rih, Ukraine, e-mail: ostapenko.ivan1996@gmail.com, ORCID: https://orcid.org/00000002-4160-6397

\section{Haliasnyi I., Gavrish T., Shanina 0.}

\title{
RESEARCH OF SURFACE PROPERTIES OF WATER-FLOUR SUSPENSIONS IN THE PRESENCE OF HYDROCOLLOIDS AND PROTEIN SUPPLEMENTS
}

Досліджено вплив гідроколоїів та білкових добавок на показник формостійкості крапель водно-борошняних суспензій на основі безглютенового борошна. Підтверджено доцільність застосування в рещептурі безглютенового бездріжджового хлібного тіста натрій карбоксиметилцелюлози та концентратів тваринних білків для утворення поліпшеної пінної структури. Встановлено залежність показника формостійкості крапель водно-борошняних суспензій від кількості внесених поліпшуючих добавок та виду безглютенової борошняна.

Ключові слова: формостійкість крапель водно-борошняних суспензій, кут змочування, натрій карбоксиметилцелюлоза, концентрат тваринного білка.

\section{Introduction}

Gluten-free products play a very important role in the preventive and curative nutrition of mankind. Initially, this applies to patients with celiac disease, as well as consumers who have various eating disorders - gluten allergy or intolerance [1]. Taking into account the achievements in the field of nutrigenomics and nutrients, the tendency to individualize diets is growing. This will help to increase the volume of the market for specialized food products, including gluten-free foods.

Bakery and culinary and confectionery flour products that do not contain gluten are one of the segments of this market. At present, the production of such specialized food products is rapidly developing.

The growth of interest in gluten-free products is due to the high prevalence of celiac disease, which is estimated to cover at least $0.5 \ldots 2.0 \%$ of the population in most European countries and the USA [2]. Compared with the countries of North America, Europe, Japan, etc., in Ukraine, the production of gluten-free products in a suf- ficient range and volumes, unfortunately, is not established. However, it is necessary to provide this category of people with specialized food products constantly.

The assortment of gluten-free flour products on the Ukrainian market is formed mainly due to imported products, which has a rather high cost. In addition, most of the gluten-free products available in the country are flour confectionery. It is clear that the preparation of a number of food products with the exception of gluten is primarily a dietary aspect. But in the production of gluten-free bakery products, the absence of gluten becomes a serious technological challenge and requires the solution of a number of technological issues.

In recent decades, many studies have been carried out to improve the quality of gluten-free bread and its nutritional properties. However, there are still problems with the development of gluten-free bread with a satisfactory structure, shelf life and cost.

In view of the foregoing, it becomes clear that there is an urgent need to develop new approaches to gluten detoxification or the production of gluten-free compositions. 
In addition, the need to develop formulas and technologies for the production of flour-free gluten-free products having a sufficient quality and an acceptable price is clearly evident.

\section{The object of research and its technological audit}

The objects of research in the work are:

- rice flour $\left(F_{\text {rice }}\right)$, corn fine grinding $\left(F_{\text {corn }}\right)$, according

to the current regulatory documentation;

- flour mixture $\left(F_{\text {rice }}: F_{\text {corn }}\right.$, respectively, $70 \%$ : $\left.30 \%\right)$;

- water-flour suspensions.

As research materials are applied:

- distilled water;

- sodium carboxymethyl cellulose (CMC) - $0.5 \%$ solution;

- concentrate of animal protein (CAP) Scanpro T95 -

$0.5 \ldots 1.5 \%$ to the weight of flour.

In the production of gluten free dough, the technological concept is as follows. First, it is necessary to ensure the maximum foaming ability of the compound mixture, and secondly, the maximum stability of such foam during the placement of the dough in baking molds.

The process of foaming is complex because of the joint influence of numerous physical and chemical, physical and mechanical and other factors. The patterns that characterize the process of foam formation depend significantly on the conditions for carrying out a particular process. The set of variable parameters, the influence of which is not always accountable, significantly complicates the possibility of an accurate quantitative assessment of the processes taking place. Nevertheless, the formation and destruction of the foam layer obeys different regularities depending on the surface properties of the solutions at the boundary with air and the mechanical properties of the liquid interlayers between the bubbles.

Summarizing the foregoing, it can be argued that in order to ensure the maximum foaming capacity and stability of the formulation mixture of a gluten-free, dough, it is necessary to study the effect of CMC and CAP on the surface properties of water-flour suspensions.

\section{The aim and objectives of research}

The aim of research is determination of $\mathrm{CMC}$ and $\mathrm{CAP}$ effect on the surface properties of water-flour suspensions using rice, corn flour and their mixtures. To achieve this aim, it is necessary to perform the following tasks:

1. To determine the contact wetting angle $(\alpha)$ o of water-flour suspensions without supplements, and also in the presence of $0.5 \% \mathrm{CMC}$ and $0.5 \ldots 1.5 \%$ CAP.

2. To determine the shape stability index (H/D) of water drops and water-flour suspensions under the conditions of adding supplements of the indicated concentrations.

3. To establish the dependence of this indicator on the use of various types of gluten-free flour in the conditions of adding supplements and without them.

\section{Research of existing solutions of the problem}

To compensate for missing gluten, scientists recommend using the functionality of various ingredients.
The research of the specialists of the world food industry is aimed at the search for gluten-free basic and auxiliary raw materials components (hydrocolloids, protein components, starches, pseudo-grained raw materials, etc.). And also on the development of new technological approaches that involve the use of enzymes, the use of high pressure, hydrothermal processing, extrusion and germination of grain and flour raw materials, fermentation of dough, etc.

Rice flour [3] and rice starch are used as the most common and widely used raw ingredients; corn flour and corn starch; potato starch; cassava starch; wheat starch [4]. Such raw materials are offered as alternative: gluten-free flour from cereals (sorghum, millet, oats) [5]; gluten-free flour with pseudo-grains (buckwheat, amaranth, quinoa) [6].

Proteins play a decisive role in determining the structure of many food products, including gluten-free bread [2, 7]. Because of their excellent functional properties, animal proteins are widely researched and used in food systems. Some animal proteins have excellent functional and organoleptic properties, but they entail a higher production cost [8].

Proteins from various sources (soy, pea, egg white and casein, etc.) can be added to the basic gluten-free compositions [7]. Proteins lead to an increase in the modulus of elasticity by crosslinking the protein network, enhancing color, flavor due to Meyer's reaction, improving the structure by improving gelling and foaming [9].

Hydrocolloids are widely used as structuring agents to simulate the visco-elastic properties of gluten. These ingredients are generally used as a substitute for gluten for their thickening ability, high water-retaining and gel-forming characteristics. They increase the volume of the dough, stabilize its foam structure by increasing the viscosity. Hydrocolloids also prevent the effect of the aqueous phase on the foam structure, improving the stability of the liquid in the films surrounding the gas bubbles [10, 11]

The overwhelming majority of works are devoted to the perspective questions of the production of yeast glutenfree bread with the use of yeast as dough disintegrators. Therefore, scientific data on the effect of hydrocolloids and animal protein concentrates on the surface properties of non-yeasted foamy dough masses in modern information sources has not been found.

\section{Methods of research}

To determine the surface properties of water-flour suspensions, the sessile-drop method is applied [11]. The diameter of the drop (in several replicates) is $6 \pm 1 \mathrm{~mm}$. This ensures that the contact angle does not depend on the diameter. Since it is known that in the case of very small drops, the influence of the surface tension of the liquid itself (the tendency to form a spherical drop), and in the case of large drops, the gravitational forces begin to dominate. By this method, the angle between a solid surface and a liquid at the contact point of three phases is measured (Fig. 1, $a$ ).

In addition, a graphical method for determining the shape stability (H/D) of a drop is used - through the ratio of the drop height in its diameter (Fig. 1, b).

The processing of the experimental data is carried out using the MS Office Excel software package (USA). 

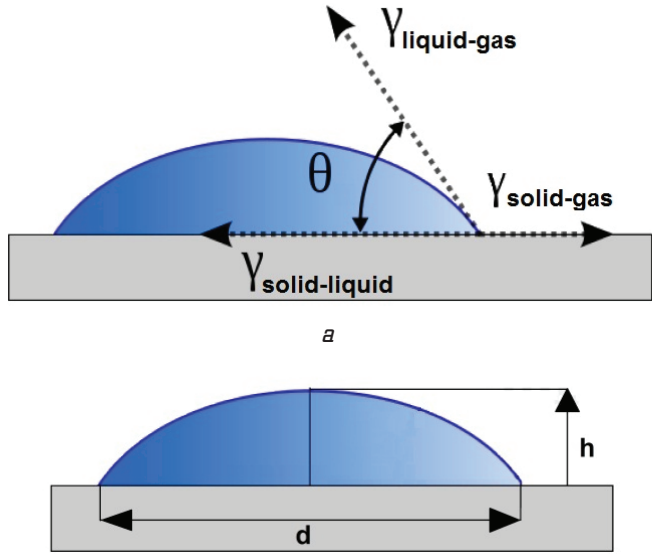

Fig. 1. Determination

$a$ - wetting angle of a liquid drop; $b$ - shape stability of a liquid drop

\section{Research results}

At the first stage of research, the wetting angle of water drops and water-flour suspensions in the presence of supplements and without them is determined. The results of the experiment are shown in Fig. 2-5, and the data of their processing are given in Table 1 .

During the experiment, a measurement time of $10 \mathrm{~s}$ (the same for all samples) is observed, since even after short exposure of the samples before measurement, a change in the shape stability of the drop.

The wetting angle (contact angle) is the main wetting characteristic. This is the angle of the surface of the liquid to the wetted surface of the solid. The liquid itself is always inside the edge angle. The tip of the wetting angle is on the wetting line, which passes through the contact line of the three phases. Characteristics of the wetting angle are given in Table 1.

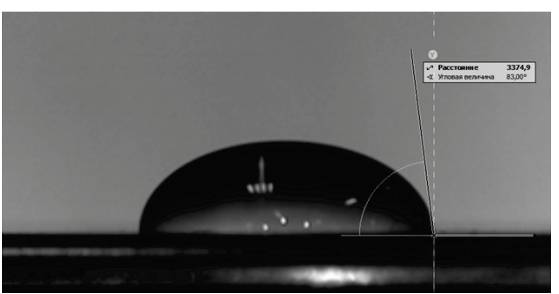

$a$

$c$

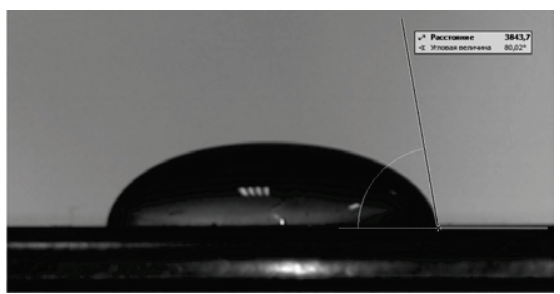

$b$

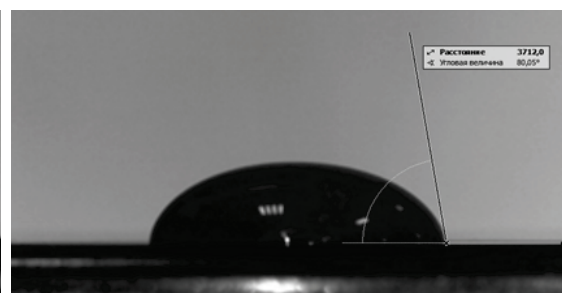

$e$

Fig. 2. Appearance of prototypes - drops of water with supplements:

$a$ - without supplements; $b-0.5 \%$ of CMC; $c-0.5 \%$ CMC+0.5\% of Scanpro T95; $d-0.5 \%$ of CMC+1.0 \% of 5canpro T95; $e-0.5 \%$ of CMC $+1.5 \%$ of 5 canpro T95

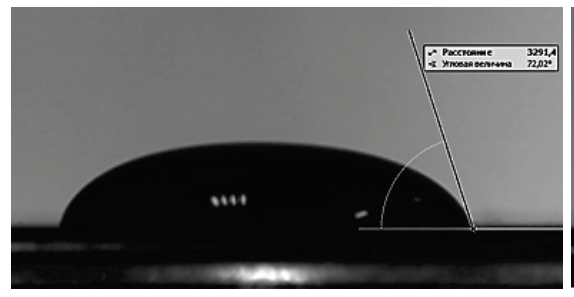

$a$

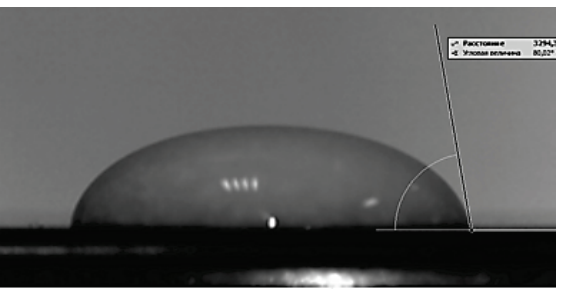

$b$

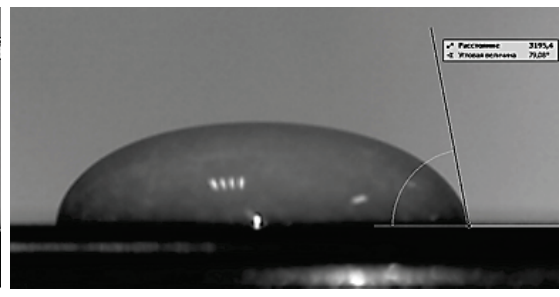

Fig. 3. Appearance of prototypes - drops of water-flour suspensions with supplements $a-F_{\text {rice }} ; b-F_{\text {rice }}+0.5 \%$ of CMC; $c-F_{\text {rice }}+0.5 \%$ of CMC+1.0\% of 5canpro T95

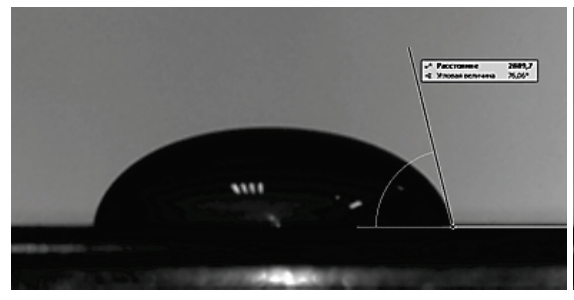

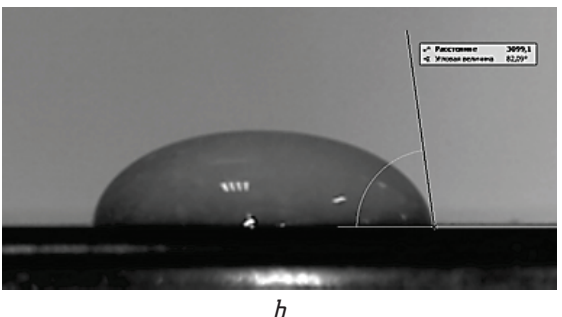

$b$

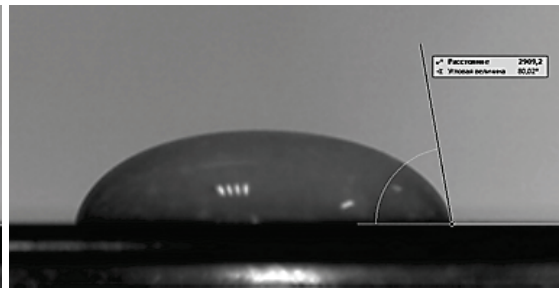

C

Fig. 4. Appearance of prototypes - drops of water with supplements: $a-F_{\text {corn }} ; b-F_{\text {corn }}+0.5 \%$ of СМС; $c-F_{\text {corn }}+0.5 \%$ of CMС+1.0\% of 5canpro T95 


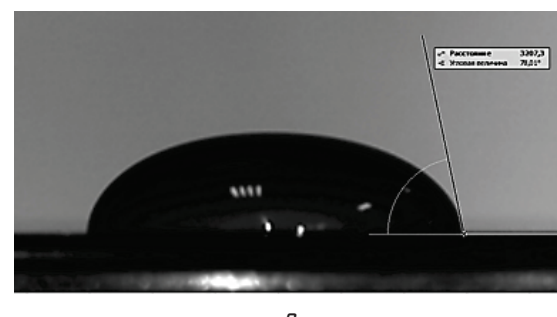

$a$

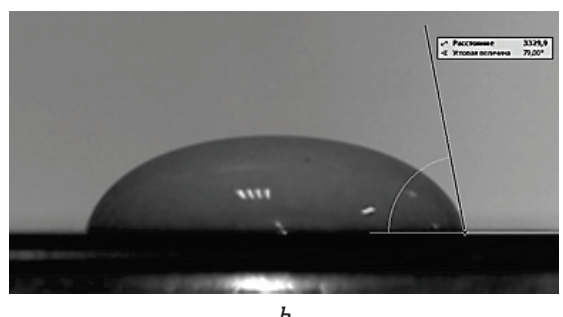

$b$

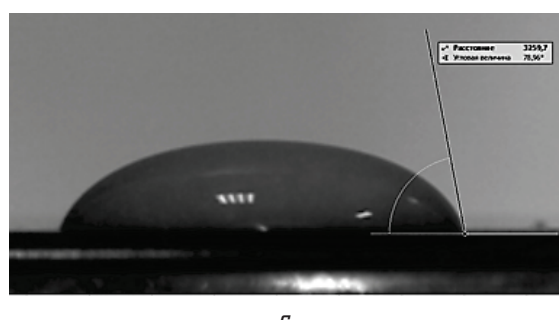

C

Fig. 5. Appearance of prototypes - drops of water with supplements:

$a-F_{\text {rice }} / F_{\text {corn }} 70 / 30 ; b-F_{\text {rice }} / F_{\text {corn }} 70 / 30+0.5 \%$ of CMC; $c-F_{\text {rice }} / F_{\text {corn }} 70 / 30+0.5 \%$ of CMC+1.0\% of 5canpro T95

Table 1

Characteristics of the wetting angle $(n=3, P \leq 0.05)$

\begin{tabular}{|c|c|c|c|c|c|c|c|c|}
\hline \multirow{3}{*}{$\begin{array}{l}\text { Type and quantity } \\
\text { of the supplement }\end{array}$} & \multicolumn{8}{|c|}{ Characteristics of the wetting angle } \\
\hline & \multicolumn{2}{|c|}{ water } & \multicolumn{2}{|c|}{ water $/ F_{\text {rice }}$} & \multicolumn{2}{|c|}{ water $/ F_{\text {corn }}$} & \multicolumn{2}{|c|}{ water $/ F_{\text {rice }} / F_{\text {corn }}$} \\
\hline & $\alpha,{ }^{\circ}$ & $\sin \alpha$ & $\alpha,{ }^{\circ}$ & $\sin \alpha$ & $\alpha,{ }^{\circ}$ & $\sin \alpha$ & $\alpha,{ }^{\circ}$ & $\sin \alpha$ \\
\hline Without supplements & 83 & 0.993 & 72 & 0.951 & 76 & 0.970 & 78 & 0.978 \\
\hline $0.5 \%$ of CMC & 80 & 0.985 & 80 & 0.985 & 82 & 0.990 & 79 & 0.982 \\
\hline $0.5 \%$ of СMС+0.5\% of СMС & 74 & 0.961 & - & - & - & - & - & - \\
\hline $0.5 \%$ of $\mathrm{CMC}+1.0 \%$ of CMC & 71 & 0.946 & 79 & 0.982 & 80 & 0.985 & 79 & 0.982 \\
\hline $0.5 \%$ of СMC+1.5\% of СMС & 80 & 0.985 & - & - & - & - & - & - \\
\hline
\end{tabular}

At the next stage of the study, the shape stability of water dropls and water-flour suspensions is determined under the conditions of introduction of supplements in Fig. 6, 7.

Analyzing the data shown in Fig. 6, the following explanations should be provided. First, the proposed supplements-structure improvers as a whole cause a reduction in shape stability, to the greatest extent - in the case of joint application. The H/D of the control sample is 32 , and in the presence of $0.5 \%$ of $\mathrm{CMC}$ with supplements 0.5...1.0 \%, CAP=20...21. Such data indicate the possibility of forming an improved foam dough structure by reducing the surface tension of the dough samples. It is possible to explain the decrease in the CAP efficiency in the amount of $1.5 \%$ by reversing the surface tension of the liquid phase of the dough (this confirms the growth of the H/D ratio to 27.6), which is due to the possible processes of drag-leavening with such amount of the supplement.
Analysis of the shape stability of droplets of waterflour suspensions (Fig. 4-7) indicates that there is some discrepancy between the experimental data and theoretical reasoning.

That is, if the $\mathrm{H} / \mathrm{D}$ for $B_{\text {rice }}$ is $21.3, B_{\text {corn }}$ is 26.5 , then for flour mixture in the ratio $B_{\text {rice }} / B_{\text {corn }} 70 / 30$ it should have a value between these two indicators (according to the proportionality rule -22.8 ).

However, such assertion would be true if there is no interaction between these kinds of flour in the waterflour suspension. Actually, this indicator for flour mixture is increased to 27.4. That is, the surface tension of the water-flour suspension from the flour mixture increases. Let's believe that this is a consequence of the intermolecular interaction between water-soluble proteins of rice and corn flour (since the proteins of the water-soluble fraction pass into the liquid phase of the suspension).

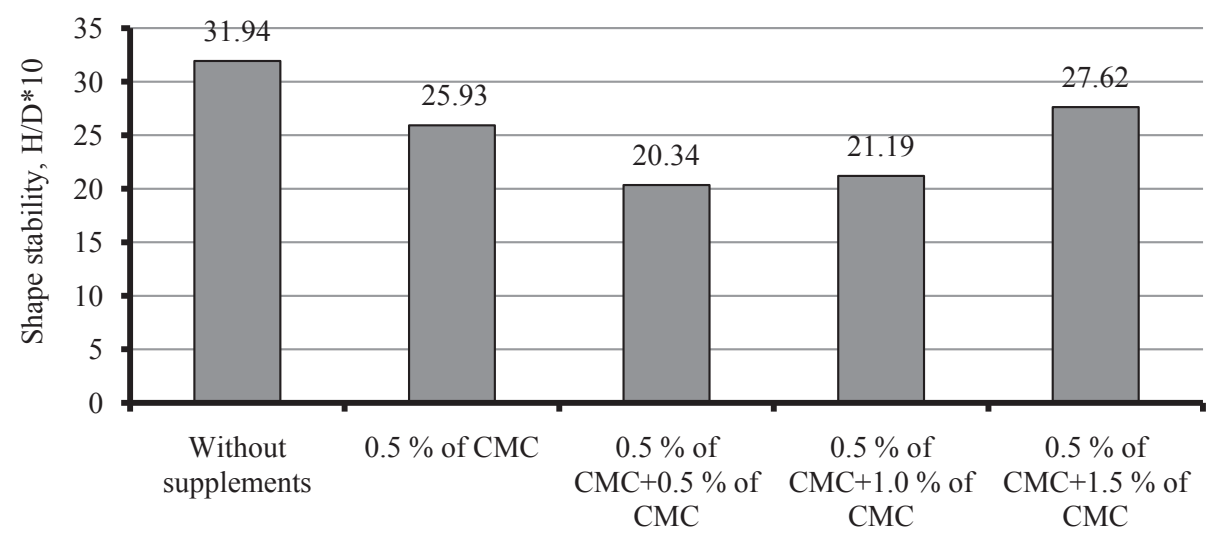

Fig. 6. Shape stability of drops of test water samples with supplements 


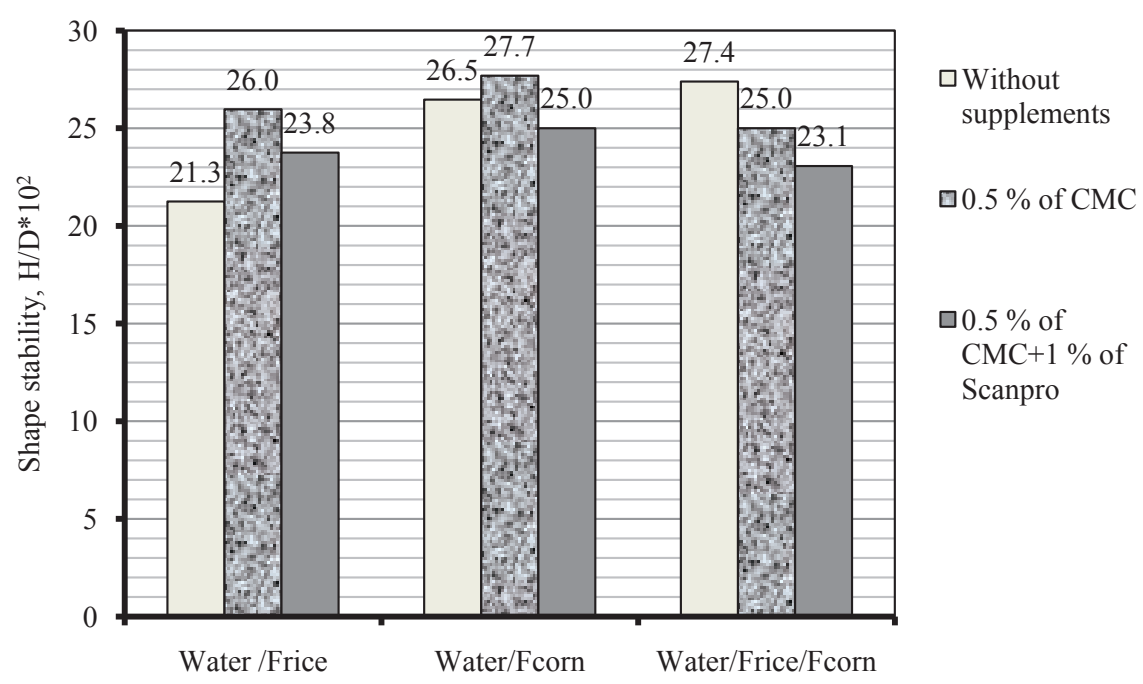

Fig. 7. Shape stability of drops of test samples of water-flour suspensions with supplements

\section{SWOT analysis of research results}

Strengths. Among the strengths of this research, it should be noted that the obtained data indicate a positive effect of CMC and CAP on the surface properties of water-flour suspensions. The proposed supplements-structure improvers as a whole cause a decrease in the shape stability, most of all in the case of joint application, indicates the formation of an improved frothy structure of the gluten-free yeast dough.

Weaknesses. The weaknesses of this research are related to the fact that the production of animal protein is 10 times more expensive than vegetable protein. As a result, over the last decade, the number of studies on the functional properties of plant proteins has increased significantly. The functionality of vegetable proteins is often inadequate because of their low solubility in the aquatic environment, which is the most common in food products, particularly bakery products.

Opportunities. Specificity of production of gluten-free non-yeasted dough by whipping is that the resulting foam structure undergoes undesirable external influences, leading to a decrease in its stability. Such factors include mixing the battered mixture with flour and placing the dough in molds. In such conditions it is important not only to get a foam system with the specified characteristics, but also to keep them during the technological process.

To develop this area of research, it is necessary to investigate complexly the foam-forming ability and stability of the foam to break down the structure of the gluten-free dough.

Threats. Difficulties in implementing the results can be due to the fact that the presence of gluten, as well as its residues in gluten-free bread, is not allowed. Therefore, producers of gluten-free products need to take into account the good quality and safety of incoming raw materials, high performance characteristics of equipment, sanitary and hygienic norms and rules, and high professionalism of personnel at the development stage of gluten-free bakery products.

\section{Conclusions}

1. It has been established that the wetting angle indicator when studying samples on water in the presence of
CMC and CAP decreases: water without supplements $-83^{\circ}$, water $+0.5 \%$ of $\mathrm{CMC}-80^{\circ}$, water $+0.5 \%$ of $\mathrm{CMC}+0.5 \%$ of Scanpro T95 $-74^{\circ}$, water $+0.5 \%$ of $\mathrm{CMC}+1.0 \%$ of Scanpro T95 $-71^{\circ}$. A decrease in the wetting angle, with the addition of supplements, indicates a decrease in the surface tension, which in turn will contribute to the improvement of the foam structure of the non-yeasted gluten-free dough for test studies.

2. It has been found that the proposed supplementsstructure improvers as a whole cause a reduction in the shape stability, to the greatest extent - in the case of joint application. So, the shape stability index of the control sample (water) is 32 , and in the presence of $0.5 \%$ of CMC with supplements $0.5 \ldots 1.0 \%$, CAP $-20 \ldots 21$. Under the conditions of CAP introduction in the amount of $1.5 \%$ an increase in the surface tension of the liquid phase of the dough is observed (H/D to 27.6). To explain the decrease in the CAP efficiency in the amount of $1.5 \%$ can be through the possible processes of drag-dropping with such amount of supplement.

3. It is determined that the $\mathrm{H} / \mathrm{D}$ for $F_{\text {rice }}-21.3, F_{\text {corn }}-$ $26.5, F_{\text {rice }} / F_{\text {corn }} 70 / 30-27.4$. According to the proportionality rule, the H/D ratio for the $F_{\text {rice }} / F_{\text {corn }}$ sample $70 / 30$ should be -22.8 , provided that there is no interaction between these kinds of flour in the water-flour suspension. Let's assume that this is a consequence of the intermolecular interaction between water-soluble proteins of rice and corn flour.

Thus, experimental studies have confirmed that the surface tension of the water-flour suspension from the flour mixture increases, which is a consequence of the intermolecular interaction between the water-soluble proteins $F_{\text {rice }}$ and $F_{\text {corn }}$. The presence of CMC and CAP in the water-flour suspension with flour mix reduces the shape stability of the drop, due to a decrease in its surface tension.

\section{References}

1. Shewry P. R., Hey S. J. Do we need to worry about eating wheat? // Nutrition Bulletin. 2016. Vol. 41, No. 1. P. 6-13. doi:10.1111/nbu.12186

2. Reilly N. R., Green P. H. R. Epidemiology and clinical presentations of celiac disease // Seminars in Immunopathology. 2012. Vol. 34, No. 4. P. 473-478. doi:10.1007/s00281-012-0311-2 
3. Rheological properties of gluten-free bread formulations / Demirkesen I. et al. // Journal of Food Engineering. 2010 Vol. 96, No. 2. P. 295-303. doi:10.1016/j.jfoodeng.2009.08.004 4. Analysis of ingredient lists of commercially available glutenfree and gluten-containing food products using the text mining technique / Do Nascimento A. B. et al. // International Journal of Food Sciences and Nutrition. 2012. Vol. 64, No. 2. P. 217-222. doi:10.3109/09637486.2012.718744

5. Marston K., Khouryieh H., Aramouni F. Evaluation of sorghum flour functionality and quality characteristics of gluten-free bread and cake as influenced by ozone treatment // Food Science and Technology International. 2014. Vol. 21, No. 8 . P. 631-640. doi:10.1177/1082013214559311

6. Torbica A., Hadnađev M., Dapcevic T. Rheological, textural and sensory properties of gluten-free bread formulations based on rice and buckwheat flour // Food Hydrocolloids. 2010 Vol. 24, No. 6-7. P. 626-632. doi:10.1016/j.foodhyd.2010.03.004

7. Supplementation of gluten-free bread with non-gluten proteins. Effect on dough rheological properties and bread characteristic Ziobro R. et al. // Food Hydrocolloids. 2013. Vol. 32, No. 2 P. 213-220. doi:10.1016/j.foodhyd.2013.01.006

8. Lusk J. L., Norwood F. B. Some Economic Benefits and Costs of Vegetarianism // Agricultural and Resource Economics Review. 2009. Vol. 38, No. 2. P. 109-124. doi:10.1017/s1068280500003142

9. Ronda F., Villanueva M., Collar C. Influence of acidification on dough viscoelasticity of gluten-free rice starch-based dough matrices enriched with exogenous protein // LWT Food Science and Technology. 2014. Vol. 59, No. 1. P. 12-20. doi:10.1016/j.lwt.2014.05.052

10. Dickinson E. Food emulsions and foams: Stabilization by particles // Current Opinion in Colloid \& Interface Science. 2010 Vol. 15, No. 1-2. P. 40-49. doi:10.1016/j.cocis.2009.11.001

11. Gorelov V. O., Dranchuk M. M. Vymiryuvannya poverkhnevoho natyahu chystykh ridyn i rozchyniv metodom lezhachoyi krapli // Metody ta prylady kontrolyu yakosti. 2003. Vol. 10. P. 31-35.

\section{ИССЛЕДОВАНИЕ ЛОВЕРХНОСТНЫХ СВОЙСТВ ВОДНО-МУЧНЫХ СУСПЕНЗИЙ В ЛРИСУТСТВИИ ГИДРОКОЛЛОИДОВ И БЕЛКОВЫХ ДОБАВОК}

Исследовано влияние гидроколлоидов и белковых добавок на показатель формоустойчивости капель водно-мучных суспензий на основе безглютеновой муки. Подтверждена целесообразность применения в рецептуре безглютенового бездрожжевого хлебного теста натрий карбоксиметилцеллюлозы и концентратов животных белков для образования улучшенной пенной структуры. Установлена зависимость показателя формоустойчивости капель водно-мучных суспензий от количества внесенных улучшающих добавок и вида безглютеновой муки.

ключевые слова: формоустойчивость капель водно-мучных суспензий, угол смачивания, натрий карбоксиметилцеллюлоза, концентрат животного белка.

Haliasnyi Ivan, Postgraduate Student, Department of Processing and Food Technologies, Petro Vasylenko Kharkiv National Technical University of Agriculture, Ukraine, e-mail: ivangalyasnyj@yandex.ru, ORCID: http://orcid.org/0000-0002-4195-9694

Gavrish Tetyana, PhD, Associate Professor, Department of Processing and Food Technologies, Petro Vasylenko Kharkiv National Technical University of Agriculture, Ukraine, ORCID: http://orcid.org/ 0000-0002-5461-8442

Shanina Olga, Doctor of Technical Sciences, Professor, Department of Processing and Food Technologies, Petro Vasylenko Kharkiv National Technical University of Agriculture, Ukraine, e-mail: avgust23@ukr.net, ORCID: http://orcid.org/0000-0003-2465-1257 